\title{
Spatio-temporal macrofaunal assemblages associated with the endangered orange coral Astroides calycularis (Scleractinia: Dendrophylliidae)
}

\author{
Alejandro Terrón-Sigler ${ }^{1,2, *}$, Patricio Peñalver-Duque ${ }^{2}$, David León-Muez ${ }^{2}$, \\ Free Espinosa Torre ${ }^{1}$
}

${ }^{1}$ Departamento de Zoología, Facultad de Biología, Universidad de Sevilla, Avda Reina Mercedes 6, 41012 Sevilla, Spain

${ }^{2}$ Asociación Hombre y Territorio, C/ Betania n ${ }^{\circ} 13$, CP 41007 Sevilla, Spain

\begin{abstract}
The orange coral Astroides calycularis is internationally protected due to its narrow distribution, its sensitivity to environmental changes and anthropogenic disturbance. Spatio-temporal macrofaunal assemblages associated with A. calycularis were studied along the southern coast of the Iberian Peninsula. A total of 878 invertebrate specimens were collected, comprising 81 species. At the 3 depths studied $(0,5$ and $10 \mathrm{~m})$, crustacean species were dominant in terms of abundance, followed by annelids and molluscs. Macrofaunal densities were higher in October and May, and lower in August and September. Janira maculosa (isopod), Lembos spp. (gammarid) and Stenothoe cavimana (gammarid) were the most abundant species, present in almost all depths and months. ANOVA analyses by month reflected significant differences in species richness and Shannon-Wiener diversity, but no differences among depth ranges and no interaction between time and depth. PERMANOVA analyses showed significant differences in the associated macrofauna for time and depth, but no interaction was observed between these factors. These results indicate the ecological relevance of this Mediterranean scleractinian coral as a habitat for many macrofaunal groups. Furthermore, the conservation of this endangered species contributes to the preservation of high marine biodiversity.
\end{abstract}

KEY WORDS: Astroides calycularis - Corals - Habitat - Associated macrofauna - Biodiversity · Conservation · Mediterranean Sea

\section{INTRODUCTION}

The Mediterranean Sea comprises less than $1 \%$ of the World Ocean (Defant 1961, Bianchi 2007) but harbours between 4 and $18 \%$ of the world's marine species, depending on the groups considered (Fredj et al. 1992, Bianchi \& Morri 2000). Coll et al. (2010) listed approximately 17000 marine species that are known to occur in the Mediterranean, although this number could be much higher. This marine biota includes a high number of endemic species (Roberts 1978, Giaccone 1999, Airoldi \& Beck 2007), with endemics comprising more than one-quarter of all Medi-

${ }^{*}$ Corresponding author: terronsigler@hombreyterritorio.org terranean species (Tortonese 1985, Fredj et al. 1992, Giaccone 1999). Ten biogeographic sectors have been described in this temperate sea (Bianchi \& Morri 2000). One of them, the Alboran Sea (Western Mediterranean), is a biodiversity hotspot due to its ecological importance as a result of the influx of Atlantic species and the physicochemical conditions of the area (Coll et al. 2010).

Despite the biodiversity found on hard substratum, there is relatively little information compared to studies conducted on soft substrata (Chintiroglou et al. 2005). Nevertheless, research regarding differences in distribution patterns on hard substratum have

() The authors 2014. Open Access under Creative Commons by Attribution Licence. Use, distribution and reproduction are unrestricted. Authors and original publication must be credited. 
shown that the distribution and abundance of organisms differs among depths (Balata et al. 2006), and that the structure of benthic assemblages may change seasonally (Coma et al. 2000, Piazzi et al. 2004, Balata et al. 2005). Accordingly, bioconstructor species play an important role, increasing habitat complexity and biodiversity (e.g. Bianchi \& Morri 1996, Porras et al. 1996, Cocito 2001). In the Mediterranean Sea, Cladocora caespitosa (a shallow-water zooxanthellate scleractinian coral), Lophelia pertusa and Madrepora oculata (a deep-water azooxanthellate scleractinian corals) are recognized as the main bioconstructors (see Kružic 2014). The fauna associated with these species has been the subject of some research (Koukouras et al. 1998, Antoniadou \& Chintiroglou 2010, D'Onghia et al. 2010, Mastrototaro et al. 2010, Calcinai et al. 2013, Kružic et al. 2013); however, none of these studies have assessed the spatiotemporal variability of the macrofaunal assemblages associated with temperate corals.

Astroides calycularis (Pallas, 1766) is an azooxanthellate scleractinian colony coral with a carbonate calcium exoskeleton (Zibrowius 1980, 1983). It inhabits rocky shores from the surface to $50 \mathrm{~m}$ depth (Rossi 1971, Ocaña et al. 2000) but is typically found in the shallow infralittoral zone (0 to $15 \mathrm{~m}$ depth), on vertical walls or inside caves (Cinelli et al. 1977, Zibrowius 1978, Kružic et al. 2002). It occupies both light and dark environments and appears to prefer a high hydrodynamism (Cinelli et al. 1977, Zibrowius 1978, 1995, Kružic et al. 2002). Population density can be locally high; throughout our study site coverage of up to $90 \%$ can be found (Terrón-Sigler et al. 2008). A. calycularis is endemic to the Mediterranean Sea, present in Italy between the Sicilian and Messina Strait and the Gulf of Naples, and in the Iberian Peninsula from the Strait of Gibraltar to Palos Cape (Murcia). It is also found in Malta, Tunis, Algeria, Morocco, Ceuta and Melilla (Spain), and it also occurs in Atlantic waters in Espartel Cape (Morocco) and La Caleta (Cádiz, Spain) as the most westerly populations (Zibrowius 1983, 1995, Bianchi 2007), probably due to the currents dispersing larvae out of the Strait of Gibraltar (Ocaña et al. 2000, CasadoAmezúa 2012, Casado-Amezúa et al. 2012).

A. calycularis is protected by national and international organisations as an endangered species (i.e. the Bern and Barcelona Conventions and CITES). Nevertheless, its relevance as a habitat for macrofaunal community has never been studied. Therefore, the aim of this study was to show the role of A. calycularis as a possible habitat for macroinvertebrate fauna.

\section{MATERIALS AND METHODS}

This study was conducted in Marina del Este beach (Granada coast, Andalusia, Spain) from August 2010 to July 2011 (Fig. 1). Colonies were collected monthly by SCUBA diving at 3 depths: 0,5 and $10 \mathrm{~m}$, selected as higher populations of this species occur in this depth range along the Andalusian coast (TerrónSigler \& León-Muez 2009). We chose a site with a rocky substrate with similar coverage of Astroides calycularis (between 50 and $75 \%$ cover) at the 3 depths. Cebrián \& Ballesteros (2004) described the zonation of the rocky benthic communities in this area, and concluded that depth was the main axis of variation. These authors observed differences among communities between lower depths $(25 \mathrm{~m})$ and the shallow infralittoral zone (5 m).

A total of 67 A. calycularis colonies were collected at 3 different depths: 22 colonies at $0 \mathrm{~m}, 23$ colonies at $5 \mathrm{~m}$ and 22 colonies at $10 \mathrm{~m}$. Colonies were covered in situ with plastic bags before they were removed in order to retain all associated fauna. The samples were fixed in $4 \%$ formalin and subsequently placed in $70 \%$ ethanol in the laboratory. The colonies were washed, the macrofauna sieved using a $0.5 \mathrm{~mm}$ mesh size, and the specimens collected were sorted and identified to species level where possible. We expressed the density of the macrofauna as the number of individuals per volume $(1000 \mathrm{ml})$ of colony. Volume of $A$. calycularis colonies was estimated as the difference between the initial and final volume when placed into a graduated cylinder with a fixed amount of water (see Pereira et al. 2006). Moreover, colony length ( $L_{\mathrm{c}}$ major axis of the colony) and colony width ( $W_{\mathrm{c}}$ minor axis of the colony) were measured, and colony area $\left(A_{c}\right)$ was calculated using the formula for an ellipse $\left(A_{\mathrm{c}}=\pi\left[L_{\mathrm{c}} \times W_{\mathrm{c}}\right] / 4\right)$, according

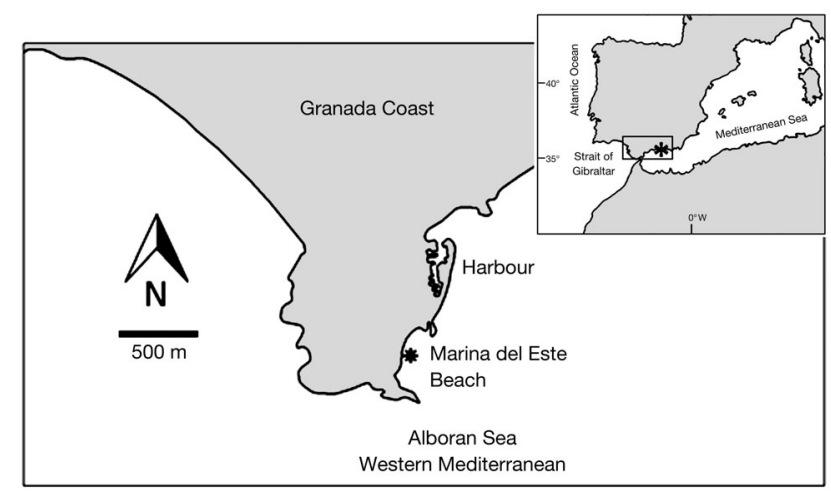

Fig. 1. Study site showing Marina del Este beach (Andalusia, Spain), where the colonies of Astroides calycularis were collected 
to Goffredo et al. (2011). The number of polyps and biovolume were also studied. We selected colony area as the main biometric parameter because it is a more accurate and representative measure of colony size than colony length (Bak \& Meesters 1998, Meesters et al. 2001, Vermeij \& Bak 2002, Nozawa et al. 2008, Goffredo et al. 2011).

All collected colonies reached in total $989 \mathrm{ml}$ of biovolume, with a mean of $15 \mathrm{ml}$ colony $^{-1}$. To standardize individual abundance since colonies had different biovolumes, we calculated abundance for $1000 \mathrm{ml}$ of coral volume, and estimated a mean of 1223 individuals based on a colony volume of $1000 \mathrm{~m}$.

The abundance of the associated macrofauna was calculated for each colony, and the total number of species $(S)$ and Shannon-Wiener diversity $\left(H^{\prime}\right)$ (Shannon \& Weaver 1963) were obtained. To test whether $S$ and $H^{\prime}$ of macroinvertebrate assemblages were similar across depth and time, we used a multifactor ANOVA with time and depth as factors (orthogonal to each other and fixed), with 6 levels for time (February, March, April, May, June and July) and 3 levels for depth $(0,5$ and $10 \mathrm{~m}) ; 3$ replicates were collected for both factors. Prior to ANOVA, the heterogeneity of variance was tested via Cochran's $C$-test. Univariate analyses were conducted with GMAV5 (Underwood et al. 2002). When statistical differences were detected, a posteriori StudentNewman-Keuls test was applied.

A permutational multivariate ANOVA (PERMANOVA) was used to test differences in associated macrofaunal assemblages across depth and time, both as fixed factors. Data were square-root transformed and a similarity matrix was calculated using the Bray-Curtis index. The percentage similarity procedure (SIMPER) was then used to calculate the contribution of each species to the dissimilarity between depths and months. Multivariate analyses were carried out using the PRIMER v6 + PERMANOVA package (Clarke 1993).

\section{RESULTS}

\section{Biometric analyses}

Colony length, width, biovolume and number of polyps all correlated positively with colony area, whose variation explained 72.5 to $94.4 \%$ of the variance. Colony length, width, biovolume and colony area all correlated positively with the number of polyps, whose variation explained 63.3 to $73.0 \%$ of the variance (Fig. 2).

Colony length, width, biovolume and number of polyps were also positively correlated with colony area for all depths. However, this correlation was greater for deeper sites: variances were 50.5 to $89.9 \%$ at $0 \mathrm{~m}, 75.2$ to $90.8 \%$ at $5 \mathrm{~m}$ and 79.0 to $97.3 \%$ at $10 \mathrm{~m}$. The highest correlation was between length and width of the colony, and colony area at each depth, but these correlations were stronger for deeper sites: 89.1 to $89.9 \%$ at $0 \mathrm{~m}, 90.3$ to $90.8 \%$ at $5 \mathrm{~m}$ and 96.5 to $97.3 \%$ at $10 \mathrm{~m}$. The weakest correlation was between colony area and number of polyps at $0 \mathrm{~m}$ (explained $50.5 \%$ of the variance).
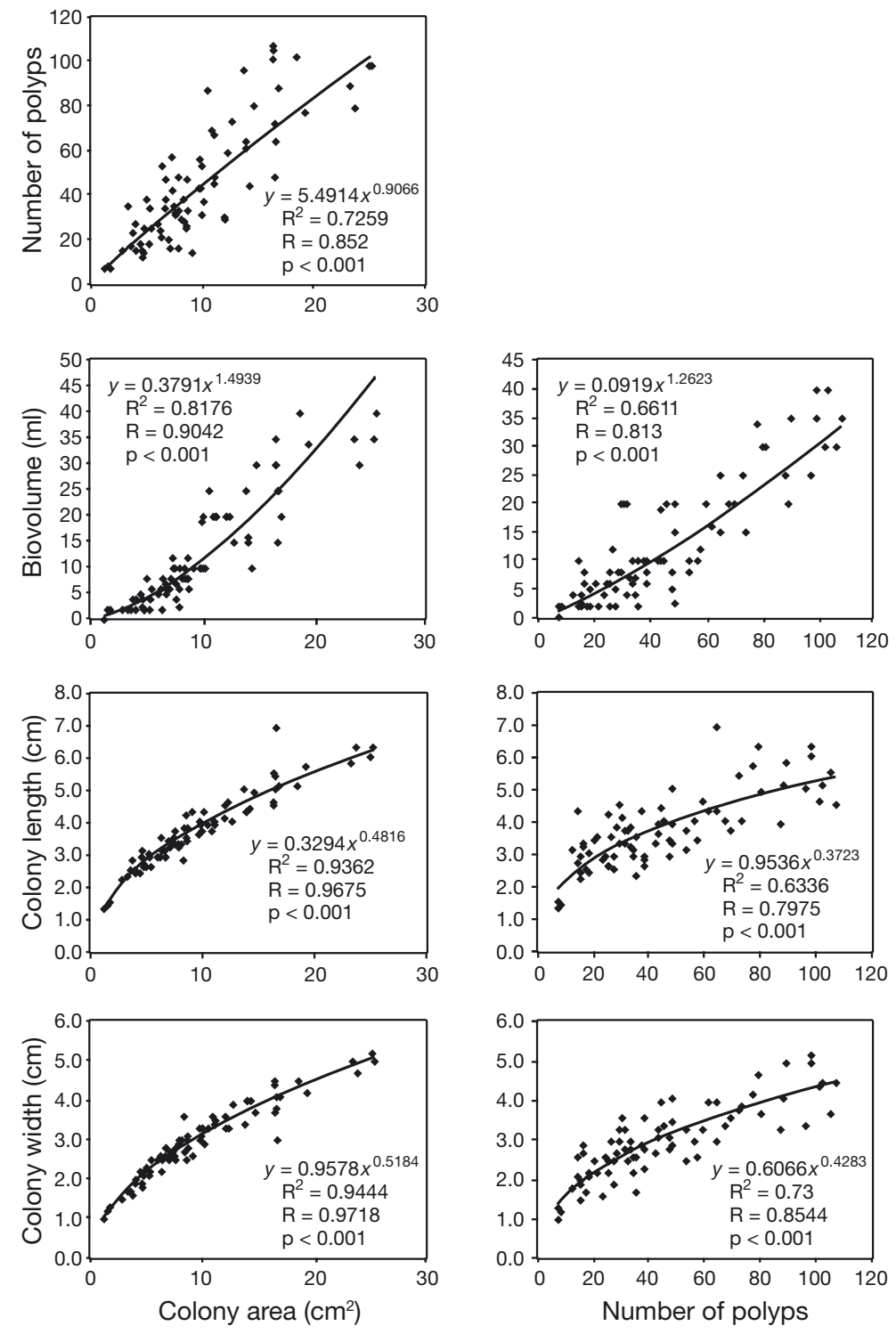

Fig. 2. Biometric analyses based on pooled data for all depths 
Within colony area, biovolume, length and colony width were positively correlated with the number of polyps in all cases, differences in which explained 41.0 to $62.4 \%$ of the variance at $0 \mathrm{~m}, 61.5$ to $75.2 \%$ at $5 \mathrm{~m}$ and 64.3 to $82.2 \%$ at $10 \mathrm{~m}$. Again, the correlations were stronger for deeper sites. Overall, colony area had a better positive correlation with the other variables than the number of polyps in the colony (Fig. 2).

\section{Associated fauna}

Invertebrate community structure

A total of 81 species were identified out of 878 invertebrate specimens that were sorted and examined (Table 1). Of these, almost $80 \%$ were crustaceans, followed in importance by annelids (more than $16 \%)$, molluscs $(2.85 \%)$, echinoderms $(2.85 \%)$, cnidarians $(0.11 \%)$ and platyhelminths $(0.11 \%)$. In this study, 38 different species of crustaceans were identified: 14 species of gammarids, 7 decapods, 6 caprellids, 4 isopods, 4 tanaids, 2 cumaceans and 1 barnacle. The most abundant crustacean group was gammarids (more than 68.5\%), followed by isopods $(20.8 \%)$. In fact, almost $90 \%$ of the crustacean specimens belonged to these 2 taxa. The most common species collected were Stenothoe cavimana and Lembos spp. (gammarids) and Janira maculosa (isopod). These species comprised almost $77 \%$ of the crustacean abundance associated with Astroides calycularis colonies.

From the annelid group, 27 polychaete species belonging to 4 orders were identified (Table 1). The most representative order in terms of number of species and specimens was Phyllodocida, with 16 species, the dominant species of which were Nereis zonata and Syllis spp. Both species represented $41 \%$ of the specimens belonging to this order. The order Sabellida was second in terms of abundance, with 7 species and $15.6 \%$ of the specimens identified; Vermiliopsis infundibulum was the most abundant species. In the order Eunicida, 3 species were identified that contributed $12.1 \%$ to the annelid total; Lumbrineris coccinea was the dominant species. The order with the lowest species number was Spionida, with only 1 species identified.

The 9 species of molluscs identified consisted of bivalves (3 species), gastropods (5 species) and polyplacophorans (1 species); the bivalve Gregariella semigranata was the most common (Table 1).

Echinoderms, cnidarians and platyhelminths were rare and represented only $1.1 \%$ of the specimens identified. The specimens of the abovementioned groups were all juveniles.

\section{Abundance}

In colonies harvested at $0 \mathrm{~m}$ depth, we found 245 specimens, with a mean of 892 ind. $1^{-1}(24.2 \%)$ in terms of density for the whole volume estimated at this depth. Crustacean species dominated $(77.4 \%$ of the total group), and 3 species accounted for more than $56 \%$ of the crustacean specimen total; S. cavimana (gammarid), J. maculosa (isopod) and Lembos spp. (gammarid). The second group in terms of density was the annelids (21.2\%), with 1 dominant species: Perinereis cultrifera (almost $6 \%$ of the total specimen density). Molluscs, cnidarians and echinoderms represented only $1.3 \%$ of the total.

At $5 \mathrm{~m}$ depth, we identified 408 specimens and estimated their abundance to be 957 ind. $1^{-1}$ (26\% of the total). The crustacean group was dominant, constituting $78.9 \%$ of the fauna at $5 \mathrm{~m}$ depth, with 3 principal species in terms of density: S. cavimana (gammarid), Lembos spp. (gammarid) and J. maculosa (isopod). These species comprised $57.9 \%$ of the total invertebrate assemblage. Annelids constituted 15.7\% of the total density, but there were no dominant species among the 20 annelid species identified, with all species having equal representation. Molluscs and echinoderms accounted the remaining $5.5 \%$.

At the deepest site $(10 \mathrm{~m})$, we found a total of 260 specimens, representing 1832 ind. $1^{-1}$ (49.8\% of the total). Crustacean species accounted for $61.4 \%$ of this assemblage, including Lembos spp. (gammarid), J. maculosa (isopod) and S. cavimana (gammarid). Although one crustacean species, Microdeutopus armatus, reached 1000 ind. $1^{-1}$, this species appeared only in 1 sample. The remaining groups were molluscs $(28.5 \%)$, annelids $(9.3 \%)$, echinoderms $(0.5 \%)$ and platyhelminths $(0.1 \%)$.

In summary, we observed the greatest abundance at greater depth. At all 3 depths, crustaceans were the dominant group, with Lembos spp. (gammarid), J. maculosa (isopod) and S. cavimana (gammarid) being the most abundant species. After crustaceans, annelids and molluscs appeared at all depths and were the most important fauna. Nevertheless, these taxa showed approximately the same proportion at each depth. Finally, echinoderms, cnidarians and platyhelminths were clearly present but did not appear at all depths.

On a monthly basis, the density of specimens was similar, although some months (i.e. October and 
Table 1. Mean abundance (ind. $\mathrm{l}^{-1}$ ) of the macroinvertebrate species associated with Astroides calycularis

\begin{tabular}{|c|c|c|c|c|c|c|c|c|c|c|c|c|c|}
\hline & \multirow{2}{*}{\multicolumn{2}{|c|}{$\begin{array}{ll} & 2010 \\
\text { Aug } & \text { Sep }\end{array}$}} & \multirow[b]{2}{*}{ Oct } & \multirow[b]{2}{*}{ Jan } & \multirow[b]{2}{*}{ Feb } & \multirow[b]{2}{*}{ Mar } & \multirow{2}{*}{$\begin{aligned} 2011 \\
\text { Apr }\end{aligned}$} & \multirow[b]{2}{*}{ May } & \multirow[b]{2}{*}{ Jun } & \multirow[b]{2}{*}{ Jul } & \multirow{2}{*}{$\overline{0 \mathrm{~m}}$} & \multicolumn{2}{|c|}{ Jepth $(\mathrm{m})$} \\
\hline & & & & & & & & & & & & $5 \mathrm{~m}$ & $10 \mathrm{~m}$ \\
\hline ARTHROPODA & & & & & & & & & & & & & \\
\hline Isopoda & & & & & & & & & & & & & \\
\hline Janira maculosa & 167 & - & 300 & 150 & 79 & 37 & 61 & 101 & 90 & 187 & 79 & 76 & 160 \\
\hline Munna sp. & - & - & - & - & - & - & - & - & - & 19 & - & 7 & - \\
\hline Paragnathia formica & - & - & 100 & - & - & 16 & - & - & 4 & 14 & 17 & 8 & 3 \\
\hline Stenosoma capito & - & - & - & - & - & - & - & - & - & 2 & - & 1 & - \\
\hline Amphipoda & & & & & & & & & & & & & \\
\hline Gammaridea & & & & & & & & & & & & & \\
\hline Amphilochus spencebatei & - & - & - & - & - & - & - & - & 22 & - & - & - & 9 \\
\hline Apocorophium acutum & - & - & - & - & - & - & 56 & - & - & - & - & - & 23 \\
\hline Autonoe spiniventris & - & - & - & - & - & - & - & 7 & 47 & 2 & - & 11 & 12 \\
\hline Elasmopus pocillimanus & - & - & - & - & 37 & - & 6 & - & - & - & 17 & - & - \\
\hline Eusiroides dellavallei & - & - & - & - & - & - & 14 & - & - & - & 6 & - & - \\
\hline Lembos spp. & - & - & 33 & - & 79 & 154 & 233 & 1304 & - & 381 & 41 & 177 & 658 \\
\hline Lembos websteri & - & - & - & 50 & 64 & 30 & 11 & - & 22 & 2 & 6 & 20 & 33 \\
\hline Leucothoe spinicarpa & - & - & 33 & 17 & 33 & - & 17 & - & - & 4 & - & 28 & - \\
\hline Liljeborgia dellavallei & - & - & - & - & - & - & 6 & - & 7 & - & 5 & - & - \\
\hline Liljeborgia psaltrica & - & - & 100 & - & - & - & - & 19 & 17 & 13 & 8 & 21 & 4 \\
\hline Maera sp. & 42 & - & - & - & - & - & - & - & - & - & 8 & - & - \\
\hline Microdeutopus armatus & 83 & - & 367 & - & - & - & - & - & - & - & - & 19 & 45 \\
\hline Stenothoe cavimana & - & - & 633 & 100 & 267 & 517 & 222 & 354 & 244 & 132 & 389 & 300 & 108 \\
\hline $\begin{array}{l}\text { Stenothoe monoculoides } \\
\text { Caprellidea }\end{array}$ & - & - & - & 100 & 37 & - & - & - & - & 3 & 1 & 13 & 15 \\
\hline Caprella sp. & - & - & - & - & 6 & - & - & - & - & - & - & 2 & - \\
\hline Caprella acanthifera & 42 & - & - & - & - & - & 22 & - & 6 & - & - & 18 & - \\
\hline Caprella grandimana & - & - & - & - & - & - & - & - & - & 3 & - & - & 1 \\
\hline Caprella penantis & - & - & - & - & - & 14 & - & - & - & - & 6 & - & - \\
\hline Pseudoprotella phasma & - & - & - & 17 & - & - & 17 & - & - & - & - & - & 9 \\
\hline $\begin{array}{l}\text { Phtisica marina } \\
\text { Cumacea }\end{array}$ & - & - & - & - & 22 & - & - & 19 & - & 15 & 8 & 9 & 5 \\
\hline Cumella limicola & - & - & - & - & - & - & - & - & 4 & 9 & - & 2 & 2 \\
\hline Cumella pygmaea & - & - & 33 & - & - & - & - & - & - & - & - & 4 & - \\
\hline Tanaidacea & & & & & & & & & & & & & \\
\hline Apseudes sp. & - & - & - & - & - & - & - & 3 & - & 6 & - & 2 & 1 \\
\hline Apseudes talpa & - & - & 167 & - & - & - & - & - & - & - & - & - & 23 \\
\hline Leptochelia dubia & 42 & - & - & 17 & - & - & - & 59 & - & 18 & 36 & 1 & 4 \\
\hline Tanais dulongii & - & - & 33 & - & - & - & 44 & 37 & - & - & 36 & - & 2 \\
\hline Decapoda & & & & & & & & & & & & & \\
\hline Alpheus glaber & - & - & - & - & - & - & - & - & - & 5 & - & 2 & - \\
\hline Anapagurus laevis & - & - & 33 & - & - & - & - & - & - & - & - & 4 & - \\
\hline Galathea nexa & - & - & 33 & - & 4 & - & - & - & - & - & - & 4 & 2 \\
\hline Pilumnus hirtellus & - & - & 33 & 33 & - & 14 & 6 & 4 & - & 7 & 14 & 7 & 1 \\
\hline Periclimenes sp. & - & - & - & - & - & - & - & - & 4 & - & - & 1 & - \\
\hline Processa edulis & - & - & 67 & 17 & 48 & - & - & - & - & - & 15 & 13 & 2 \\
\hline Pasiphaea sivado & - & - & - & - & - & - & - & - & - & 5 & - & 2 & - \\
\hline Cirripeda & & & & & & & & & & & & & \\
\hline Balanus sp. & - & - & - & - & 8 & - & - & - & - & - & 2 & - & 2 \\
\hline Chelicerata & & & & & & & & & & & & & \\
\hline Pycnogonida indet & - & - & - & - & - & - & - & - & 3 & - & - & 1 & - \\
\hline MOLLUSCA & & & & & & & & & & & & & \\
\hline Bivalvia & & & & & & & & & & & & & \\
\hline Arca noae & - & - & - & - & - & - & - & 3 & - & - & - & 1 & - \\
\hline Gregariella semigranata & - & - & - & - & - & - & - & 1111 & 31 & 17 & 3 & 4 & 467 \\
\hline Modiolus barbatus & 42 & - & - & - & - & - & - & - & - & - & - & 7 & - \\
\hline Gastropoda & & & & & & & & & & & & & \\
\hline Coralliophila sp. & - & - & - & - & - & - & - & 7 & 3 & 7 & - & 4 & 3 \\
\hline Diodora gibberula & - & - & - & - & - & - & - & - & 3 & - & - & 1 & - \\
\hline Nassarius sp. & - & - & - & - & - & - & - & 7 & - & 3 & - & 3 & 1 \\
\hline Nassarius incrassatus & - & - & - & - & - & - & - & - & 94 & - & - & - & 39 \\
\hline Nassarius reticulatus & - & - & - & - & - & - & - & - & 28 & 2 & - & 1 & 11 \\
\hline Polyplacophora & & & & & & & & & & & & & \\
\hline Chiton sp. & - & 167 & - & 17 & - & - & - & - & - & - & - & 24 & - \\
\hline
\end{tabular}


Table 1 (continued)

\begin{tabular}{|c|c|c|c|c|c|c|c|c|c|c|c|c|c|}
\hline & \multicolumn{3}{|c|}{2010} & \multicolumn{7}{|c|}{-2011} & \multicolumn{3}{|c|}{ Depth $(\mathrm{m})$} \\
\hline & Aug & Sep & Oct & Jan & Feb & Mar & Apr & May & Jun & Jul & $0 \mathrm{~m}$ & $5 \mathrm{~m}$ & $10 \mathrm{~m}$ \\
\hline CNIDARIA & & & & & & & & & & & & & \\
\hline $\begin{array}{l}\text { Actinia sp. } \\
\text { PLATYHELMINTHES }\end{array}$ & - & - & - & 17 & - & - & - & - & - & - & 2 & - & - \\
\hline $\begin{array}{l}\text { Turbellaria indet. } \\
\text { ANNELIDA }\end{array}$ & - & - & - & - & - & - & - & - & - & 3 & - & - & 1 \\
\hline Eunicida & & & & & & & & & & & & & \\
\hline Lumbrineris coccinea & - & - & - & - & - & - & - & 28 & 11 & 34 & 2 & 18 & 10 \\
\hline & - & - & - & - & - & - & - & - & - & 3 & - & - & 1 \\
\hline $\begin{array}{l}\text { Scoletoma sp. } \\
\text { Phyllodocida }\end{array}$ & - & - & - & - & 6 & - & - & - & - & 2 & - & 3 & - \\
\hline Glycera sp. & - & - & - & 33 & 45 & 67 & 56 & - & 6 & - & 41 & 2 & 32 \\
\hline Glycera tesselata & - & - & 167 & - & - & - & - & - & - & - & - & - & 23 \\
\hline Lepidonotus clava & - & - & - & - & 4 & 19 & - & 9 & - & 3 & - & 7 & 7 \\
\hline Neanthes irrorata & - & - & 33 & - & - & - & - & - & - & - & - & 4 & - \\
\hline Nereis sp. & - & - & - & - & - & - & - & - & - & 2 & - & 1 & - \\
\hline Nereis zonata & - & - & - & - & - & - & - & 19 & 19 & 60 & 16 & 8 & 15 \\
\hline Perinereis sp. & - & - & - & - & - & 22 & - & - & - & 2 & - & 9 & - \\
\hline Perinereis cultriífera & 42 & 167 & - & - & 4 & - & 28 & - & 4 & - & 25 & 9 & 11 \\
\hline Pholoe minuta & - & - & - & - & - & - & - & - & 11 & 3 & - & - & 6 \\
\hline Phyllodoce sp. & - & - & - & - & - & - & - & - & 3 & 2 & - & 2 & - \\
\hline Platynereis dumerilii & - & - & 33 & 17 & 10 & 36 & 11 & 7 & 7 & 5 & 21 & 17 & - \\
\hline Syllis spp. & - & - & 167 & - & 28 & 16 & 11 & 37 & 19 & 8 & 32 & 11 & 27 \\
\hline Syllis gracilis & 42 & - & 33 & 33 & - & - & - & - & - & 16 & 17 & 3 & 4 \\
\hline Syllis hyaline & - & - & 33 & - & - & - & - & - & - & 3 & 5 & - & 1 \\
\hline Syllis variegate & - & - & - & - & - & - & - & - & 3 & 3 & - & 1 & 1 \\
\hline $\begin{array}{l}\text { Websterinereis glauca } \\
\text { Sabellida }\end{array}$ & - & - & - & - & - & - & - & 4 & 16 & 9 & 10 & - & 1 \\
\hline Branchiomma sp. & - & - & - & - & - & - & - & - & - & 3 & - & - & 1 \\
\hline Hydroides pseudouncinatus & - & - & - & - & - & - & 11 & - & - & - & - & 4 & - \\
\hline Protula tubularia & - & - & - & - & 11 & - & - & - & - & - & - & 4 & - \\
\hline Sabella sp. & - & - & - & - & - & - & - & - & 56 & 7 & 3 & - & 23 \\
\hline Serpula sp. & - & - & - & - & - & 19 & - & - & - & 6 & - & 7 & 2 \\
\hline Serpula concharum & - & - & - & - & 26 & - & - & - & - & - & - & 9 & 2 \\
\hline $\begin{array}{l}\text { Vermiliopsis infundibulum } \\
\text { Spionida }\end{array}$ & - & 167 & 67 & 50 & - & 22 & 11 & - & - & - & 18 & 30 & 2 \\
\hline $\begin{array}{l}\text { Spionidae sp. } \\
\text { ECHINODERMA } \\
\text { Ophiuroidea }\end{array}$ & - & - & - & - & - & - & - & - & - & 6 & - & 1 & 1 \\
\hline Amphiura sp. & - & - & - & - & 6 & - & - & - & - & - & - & 2 & - \\
\hline $\begin{array}{l}\text { Ophiura ophiura } \\
\text { Holothuroidea }\end{array}$ & - & - & - & - & - & - & 28 & 4 & - & 12 & 2 & 4 & 13 \\
\hline $\begin{array}{l}\text { Holothuroidea indet. } \\
\text { Equinoidea }\end{array}$ & - & - & - & - & - & - & 11 & - & - & - & 5 & - & - \\
\hline Paracentrotus lividus & - & - & - & - & - & - & - & - & - & 3 & - & - & 1 \\
\hline
\end{tabular}

May) showed higher densities, whereas densities in August and September were lower. Lembos spp. (gammarid), J. maculosa (isopod) and S. cavimana (gammarid) were present in almost all months in a similar proportion.

Species richness $(S)$ and Shannon-Wiener diversity $\left(H^{\prime}\right)$

Monthly counts of $S$ and $H^{\prime}$ showed significant differences (Table 2), increasing considerably in July
(Fig. 3) to values double those of the other months. No differences were detected for $S$ and $H^{\prime}$ in terms of depth, but the greatest value was achieved at $5 \mathrm{~m}$ depth $\left(S=6.22 \pm 1 ; H^{\prime}=1.3 \pm 0.13\right)$ (Table 2, Fig. 3). Additionally, there was no recorded interaction between time and depth (Table 2).

PERMANOVA analyses showed significant differences in invertebrate assemblages associated with A. calycularis colonies for time and depth $(\mathrm{p}<0.001)$, although no interaction was observed between these factors (Table 3 ). 
Table 2. Results of the 2-factor ANOVA for Shannon-Wiener diversity and species richness for the macrofauna assemblage associated with Astroides calycularis. NS: not significant; ${ }^{* * *} \mathrm{p}<0.001$

\begin{tabular}{|c|c|c|c|c|c|c|c|}
\hline \multirow[t]{2}{*}{ Source of variation } & \multirow[t]{2}{*}{ df } & \multicolumn{3}{|c|}{-Species richness $(S)$} & \multicolumn{3}{|c|}{ - Shannon diversity $\left(H^{\prime}\right)$} \\
\hline & & MS & $F$ & $\mathrm{p}$ & MS & $F$ & $\mathrm{p}$ \\
\hline Time & 5 & 2,9025 & 12,10 & $0.0000^{* * *}$ & 1,3708 & 5,85 & $0.0005^{* * *}$ \\
\hline Depth & 2 & 0,4771 & 1,99 & 0.1516 & 0,2186 & 0,93 & 0.4030 \\
\hline Time $\times$ Depth & 10 & 0,3019 & 1,26 & 0.2896 & 0,3745 & 1,60 & 0.1471 \\
\hline Residual & 36 & 0,2399 & & & 0,2345 & & \\
\hline Total & 53 & & & & & & \\
\hline Cochran's $C$-test & & $\mathrm{C}=0.2673 \mathrm{NS}$ & & & $\mathrm{C}=0.1653 \mathrm{NS}$ & & \\
\hline Transformation & & Sqrt & & & None & & \\
\hline
\end{tabular}
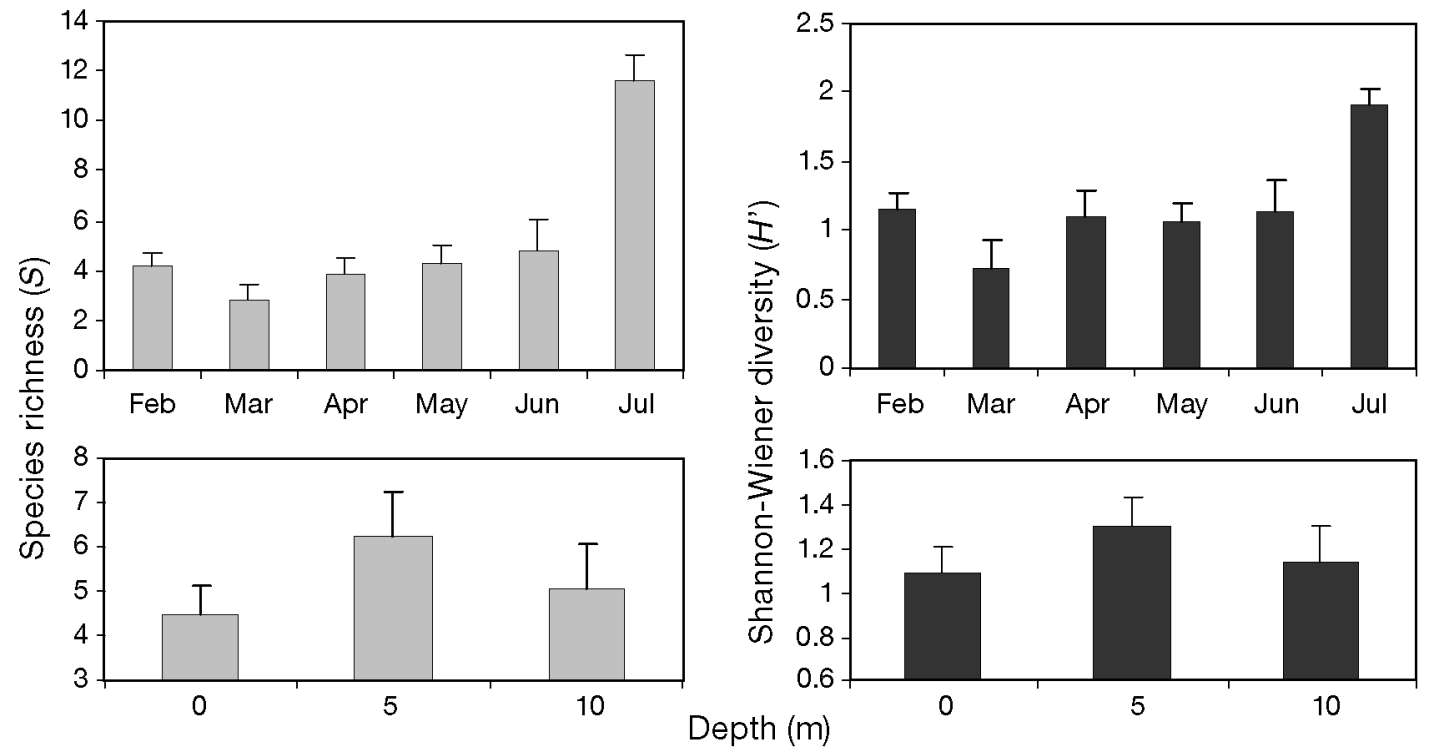

Fig. 3. Temporal and bathymetric changes in species richness and Shannon-Wiener diversity of macrofauna associated with Astroides calycularis, monthly and by depth. Data are mean + SE

\section{DISCUSSION}

To our knowledge, there have been no spatiotemporal studies on invertebrate communities associated with scleractinian corals in the Mediterranean Sea, despite the fact that information concerning these associated assemblages is crucial towards understanding the trophic web connections and health of marine ecosystems and habitats. Although there have been studies regarding species associated with scleractinian corals in the Mediterranean Sea (Koukouras et al. 1998, Castellanos et al. 2003, Richter \& Luque 2004, Conradi et al. 2006, Taviani et al. 2009, Antoniadou \& Chintiroglou 2010), these studies have contributed little towards our knowledge of the associated communities' spatio-temporal patterns. This is the first spatio-temporal study concerning the entire macroinvertebrate community associated with
Astroides calycularis (Scleractinian; Dendrophyllidae). Knowledge of this species and its associated community composition will provide information about ecosystem health, as well as Mediterranean habitats and species (García-Gómez 2007).

\section{Biometric analyses}

Goffredo et al. (2011) reported positive correlations between colony length, width or the number of polyps and colony area, and between colony length, width or area and the number of polyps on colonies of A. calycularis in Italy at 7 to $10 \mathrm{~m}$ depth. Colony area and polyp number explained 74.7 to $91.6 \%$ and 68.7 to $90.9 \%$ of the variance, respectively, in that study. In our study, we record similar results, with 72.5 to $94.4 \%$ and 63.3 to $73.0 \%$ of the variance, respec- 
Table 3. Results of PERMANOVA analysis for macrofauna assemblages associated with Astroides calycularis, based on Bray-Curtis dissimilarities of square root transformed data. NS: not significant; ${ }^{*} p<0.001$

\begin{tabular}{|lrccc|}
\hline Source of variation & df & MS & $F$ & $p$ \\
\hline Time & 9 & 5760,9 & 2,1953 & $0.001^{*}$ \\
Depth & 2 & 6740,8 & 2,5687 & $0.001^{*}$ \\
Time $\times$ Depth & 16 & 2968,9 & 1,1314 & 0.155 \\
Residual & 36 & 2624,1 & & \\
Total & 63 & & & \\
Transformation & & Sqrt & & \\
\hline
\end{tabular}

tively. We also show that these correlations are stronger at greater depths $(0<5<10 \mathrm{~m})$. Similar to Goffredo et al. (2011) with the same species, and to findings of other authors who studied different scleractinian corals (e.g. Vermeij \& Bak 2002, Nozawa et al. 2008), we report that colony area, as a representative colony size parameter throughout the coral's life history, is a good parameter for wildlife managers interested in understanding the dynamics of coral populations. Moreover, we demonstrate that it is necessary to take into account the depth of colonies, because colony area changes according to physical (e.g. hydrodynamic, depth, sedimentation) or biological (e.g. symbiosis, competition, and predation) conditions (Zibrowius 1980, Chevalier \& Beauvais 1987).

\section{Associated fauna}

In the Mediterranean Sea, Cladocora caespitosa is the only shallow-water scleractinian coral that may be considered as an ecosystem engineer (Peirano et al. 1999, Morri et al. 2001), forming large colonies with considerable interstitial space that provides habitat for a high diversity of associated fauna (Koukouras et al. 1998). Indeed, in the Eastern Mediterranean, studies of $C$. caespitosa have demonstrated high zoobenthos biodiversity associated with this coral, with up to 242 associated macrobentic species (Koukouras et al. 1998, Antoniadou \& Chintiroglou 2010). Globally, annelids are the dominant species associated with these colonies, followed by molluscs and crustaceans. These studies concur that the associated assemblages are probably differently structured among individual colonies and banks. In the present study, we found 81 macroinvertebrate species associated with $A$. calycularis and noted clear differences between depth and season, with crustaceans being the dominant species, followed by annelids and molluscs. Similarly, C. caespitosa showed crustacean dominance in shallow waters while polychaetes were dominant in deeper waters (Koukouras et al. 1998). Moreover, in one study regarding the epifaunal assemblages associated with 2 gorgonians (Eunicella gazelle and Leptogorgia lusitanica) from the south of the Iberian Peninsula, the dominant group was arthropods (mainly crustaceans), followed by molluscs and annelids (Carvalho et al. 2014).

In the Western Mediterranean Sea, many studies have focused on macrofaunal assemblages associated with algae. Seaweeds have an important role as a spatial complex within the substratum, creating a 3-dimensional habitat that increases species richness and diversity relative to unvegetated habitats (Dean \& Connell 1987). Other studies have described the associated fauna that inhabits algae throughout the Alboran Sea (Mediterranean area), and all have shown the prevalence of crustaceans over other groups such as annelids, molluscs and echinoderms (SánchezMoyano \& García-Gómez 1998, Sánchez-Moyano et al. 2000, Izquierdo \& Guerra-García 2011, Pacios et al. 2011, Guerra-García et al. 2006, 2009a, 2012), as also occurs in A. calycularis. Guerra-García et al. (2011) identified 41 crustacean species on Asparagopsis armata, whereas for Corallina elongata, one of the most important algae in the intertidal ecosystem (Pérez-Cirera \& Maldonado 1982, Guerra-García et al. 2006), a total of 78 crustacean species were found (Izquierdo \& Guerra-García 2011). We found 39 crustacean species, a value similar to those reported for algae. Guerra-García et al. (2011) indicated that the different faunal composition on 4 species of algae might be due to the differences in algal morphology. $C$. elongata and $A$. armata are native and invasive seaweeds, respectively, in the Mediterranean Sea that cohabit with A. calycularis in our study area and maintain a high diversity of peracarid crustacean assemblages (Pacios et al. 2011, Guerra-García et al. 2012). The most common associated species hosted by $C$. elongata are Caprella penantis (caprellid) and Stenothoe monoculoides (gammarid), among others (Guerra-García et al. 2010). Alternatively, A. armata hosts Aora spinicornis, Apherusa bispinosa, Dexamine spiniventris (gammarids) and Dynamene magnitorata (isopod) as dominant species (Pacios et al. 2011, Guerra-García et al. 2012). Janira maculosa (isopods), Lembos spp. (gammarid) and Stenothoe cavimana (gammarid) are the dominant species associated with A. calycularis colonies. Therefore, peracarid species were different from those reported on both seaweeds, and only the genera Stenothoe (gammarid) is common between $A$. calycularis and $C$. elongata. Thus, macrofaunal assemblages appear to be host- 
dependent. Furthermore, the bright orange colour of the 2 dominant species observed in A. calycularis (J. maculosa and $S$. cavimana) suggests a relationship between the coral and its associated species. The nature of this relationship (obligated/facultative, see Castro 1976 or trophic/cryptic) still needs to be clarified.

On the other hand, both Stenothoe spp. and Lembos websteri were associated with C. caespitosa, but neither was dominant. Leucothoe spinicarpa and the genera Lilgeborgia, Microdeutopus and Maera were common in both scleractinian species, being dominant in the $C$. caespitosa colonies from shallow waters (Koukouras et al. 1998).

Several species from genera Gnathia (isopods) have been described in association with A. calycularis in the south side of Alboran Sea, some of them being very abundant (Castellanos et al. 2003); however, this genus did not appear in our study. A plausible hypothesis would be that the authors could have mixed species from adjacent substrates with those associated with A. calycularis as a result of the methods used to collect them. They removed the colonies directly, without using plastic bags to isolate the associated assemblages. Alternatively, the genus Gnathia is absent or rare on samples of many seaweeds (Stypocaulon, Asparagopsis and Corallina) along the north side of the Alboran Sea (GuerraGarcía et al. 2009b, Izquierdo \& Guerra-García 2011, Pacios et al. 2011, Soler \& Guerra-García 2011). Therefore, it can be expected that this genus would also be absent from A. calycularis colonies in this area.

Some genera of decapods were found associated with A. calycularis in the present study (Anapagurus, Galathea, Pilumnus, Periclemenes and Alpheus). All of these genera have been reported from coralligenous assemblages in the Alboran Sea (García-Muñoz et al. 2008). In the Eastern Mediterranean Sea, the genera Galathea, Pilumnus, Periclemenes and Alpheus were associated with $C$. caespitosa, but no single genus was dominant (Koukouras et al. 1998).

Annelids were the second most important group within the macrofaunal assemblages associated with the orange coral. Nevertheless, there were no dominant species; only Perinereis cultrifera (polychaete) reached a high abundance at $0 \mathrm{~m}$ depth. In the Chafarinas Islands, López (1995) identified polychaetes in dead colonies of A. calycularis, but no type of relationship was reported. Annelids are generalist habitat species, and it is the physical and/or environmental factors (e.g. depth) of an area that influence their preference to settle in different substrata. However, polychaetes were dominant in deeper colonies of $C$. caespitosa, common species being Hydroides pseudouncinatus, Lepidonotus clava, Lumbrineris coccinea and Syllis gracilis (Koukouras et al. 1998).

Scleractinian corals act as structural engineers (Jones et al. 1994), contributing to an increase in habitat complexity and surface topography, which promotes biodiversity by mediating competition or predation (Menge 1976, Holt 1987, Hixon \& Menge 1991, Coker et al. 2009). The symbiotic associations with corals provide many benefits for invertebrate assemblages; corals provide a large surface area on and in which they can live, as well as refuges from predation, food in the form of coral tissue, mucus and its associated detritus and a hard skeleton used as a substratum by specialised burrowers (Castro 1988). Taking this into account, the molluscs, echinoderms, platyhelminths and cnidarians found associated with A. calycularis might use the coral skeleton as a refuge against potential predators, although these groups are less abundant. Richter \& Luque (2004) observed Epitoniem dendrophylliae (Gastropoda: Mollusca) feeding on A. calycularis. However, this taxon is a rare species in shallow waters (Gofas et al. 2011), and consequently E. dendrophylliae did not appear in the present study, where depth ranged from 0 to $10 \mathrm{~m}$.

Univariate analyses (species-independent), showed that macrofaunal composition associated with $A$. calycularis colonies differed through time, with a greater diversity in summer. This pattern has been previously observed in macrofaunal assemblages associated with seaweeds in the Mediterranean Sea (e.g. Guerra-García et al. 2010) and might be because some temperate species show peak abundances in summer and marked declines in winter (Keith 1971, Thom et al. 1995, Ashton 2006). Alternatively, the number of species and diversity did not show differences with depth. However, the PERMANOVA (species-dependent) detected that faunal assemblages changed with time and depth. Factors such as seawater temperature and wave action might be a seasonal reason for the vertical distribution of associated macrofauna (Neto 2000). In fact at $0 \mathrm{~m}$, hydrodynamism is greater due to strong wave action, whereas at deeper sites the impact of this factor is greatly reduced, as demonstrated by Cebrián \& Ballesteros (2004) in the same area. It has been pointed out that wave action affects patterns of distribution in the associated macrofauna in the intertidal zone (Chavanich \& Wilson 2000). Oxygen concentration might be an additional factor that affects the patterns of macrofaunal assemblages associated with seaweeds (Guerra-García \& Izquierdo 2010). Additionally, weather conditions, competition or preda- 
tion might determine the associated macrofauna. More information concerning these factors and their interaction with macrofaunal assemblages is necessary.

The macrofaunal community composition of $A$. calycularis was previously unknown. This study has shown that this endangered and seascape-forming coral from the Western Mediterranean Sea maintains a diverse associated community that changes spatially and seasonally. Although more research is required, this study has provided important information about the potential role of $A$. calycularis in the trophic foodwebs of the Mediterranean Sea rocky shore. Moreover, knowledge of macrofaunal assemblages is essential as a baseline to evaluate disturbances due to natural and/or anthropogenic factors. In this context, this information is crucial to the future conservation framework of the endangered coral $A$. calycularis.

Acknowledgements. Our research was supported by the Regional Government of Andalusia (General Office of Environment Management, Regional Ministry of Environment), and we thank Eduardo Fernández Tabales for technical assistance. We also thank the General Office of Marine Protected Area from Spanish Estate (National Ministry of Environment). Financial support for this work was provided by the Asociación Hombre y Territorio (www.hombrey territorio.org). Special thanks to our colleagues L. Moreno and F. Luengo for their help during the field work and to J. M. Guerra-García, E. Baeza, M. Ros, V. Rubio, F. Sedano, E. Martí, M. Infante and V. Clapés for their assistance with sieving, sorting and taxonomic identification. Three anonymous reviewers gave comments which improved the quality of the manuscript. The experiments complied with current Spanish laws. Colonies collected have been analyzed to study additional topics of the biology and ecology of the species.

\section{LITERATURE CITED}

Airoldi L, Beck MW (2007) Loss, status and trends for coastal marine habitats of Europe. Oceanogr Mar Biol Annu Rev 45:345-405

Antoniadou C, Chintiroglou C (2010) Biodiversity of zoobenthos associated with a Cladocora caespitosa bank in the north Aegean Sea. Rapp Comm Int Mer Médit 39:432

Ashton GV (2006) Distribution and dispersal of the nonnative caprellid Amphipoda Caprella mutica (Schurin 1935). PhD thesis, University of Aberdeen

Bak RPM, Meesters EH (1998) Coral population structure: the hidden information of colony size frequency distributions. Mar Ecol Prog Ser 162:301-306

Balata D, Piazzi L, Cecchi E, Cinelli F (2005) Variability of Mediterranean coralligenous assemblages subject to local variation in turbidity and sediment deposits. Mar Environ Res 60:403-421

Balata D, Acunto S, Cinelli F (2006) Spatio-temporal variability and vertical distribution of a low rocky subtidal assemblage in the north-west Mediterranean. Estuar Coast Shelf Sci 67:553-561

> Bianchi CN (2007) Biodiversity issues for the forthcoming tropical Mediterranean Sea. Hydrobiologia 580:7-21

> Bianchi CN, Morri C (1996) Ficopamatus 'reefs' in the Po River Delta (Northern Adriatic): their constructional dynamics, biology, and influence of brackish water biota. Mar Ecol 17:51-66

> Bianchi CN, Morri C (2000) Marine biodiversity of the Mediterranean Sea: situation, problems and prospects for future research. Mar Pollut Bull 40:367-376

> Calcinai B, Moratti V, Martinelli M, Bavestrello G, Taviani M (2013) Uncommon sponges associated with deep coral bank and maerl habitats in the Strait of Sicily (Mediterranean Sea). Ital J Zool 80:412-423

Carvalho S, Cúrdia J, Pereira F, Guerra-García JM, Santos MN, Cunha M (2014) Biodiversity patterns of epifaunal assemblages associated with the gorgonians Eunicella gazella and Leptogorgia lusitanica in response to host, space and time. J Sea Res 85:37-47

Casado-Amezúa P (2012) Genetic assessment of population structure and connectivity in two endemic Mediterranean corals: Astroides calycularis (Pallas, 1766) and Cladocora caespitosa (Linnaeus, 1767). PhD thesis, Universidad de Alcalá de Henares

Casado-Amezúa P, Goffredo S, Templado J, Machordom A (2012) Genetic assessment of population structure and connectivity in the threatened Mediterranean coral Astroides calycularis (Scleractinia, Dendrophylliidae) at different spatial scales. Mol Ecol 21:3671-3685

Castellanos C, Hernández-Vega S, Junoy J (2003) Isópodos marinos (Crustacea: Isopoda) de las islas Chafarinas (Mediterráneo occidental). Bol Inst Esp Oceanogr 19: 219-233

Castro P (1976) Brachyuran crabs symbiotic with scleractinian corals: a review of their biology. Micronesica 12:99-110

Castro P (1988) Animal symbioses in coral reef communities: a review. Symbiosis 5:161-184

Cebrián E, Ballesteros E (2004) Zonation patterns of benthic communities in an upwelling area from the western Mediterranean (La Herradura, Alboran Sea). Sci Mar 68: 69-84

> Chavanich S, Wilson KA (2000) Rocky intertidal zonation of gammaridean amphipods in Long Island Sound, Connecticut. Crustaceana 73:835-846

Chevalier JP, Beauvais L (1987) Ordre des Scleractiniaires. XI. Systématique. In: Doumenc D (ed) Traité de Zoologie, Vol 3. Masson, Paris, p 679-764

Chintiroglou C, Antoniadou C, Vafidis D, Koutsoubas D (2005) A review on the biodiversity of hard substrate invertebrate communities in the Aegean Sea. Mediterr Mar Sci 6:51-62

Cinelli F, Fresi E, Mazzella L, Pansini M, Pronzato R, Svoboda A (1977) Distribution of benthic phyto- and zoocoenoses along a light gradient in a superficial marine cave. In: Keegan BF, Ceidigh PO, Boaden PJS (eds) Biology of benthic organisms. Pergamon Press, Oxford, p 173-183

- Clarke KR (1993) Non-parametric multivariate analyses of changes in community structure. Aust J Ecol 18:117-143

Cocito S (2001) Bioconstruction and biodiversity: their mutual influence. Sci Mar 68(Suppl 1):137-144

> Coker DJ, Pratchett MS, Munday PL (2009) Coral bleaching and habitat degradation increase susceptibility to predation for coral-dwelling fishes. Behav Ecol 20:1204-1210 
Coll M, Piroddi C, Steenbeek J, Kascher K and others (2010) The biodiversity of the Mediterranean Sea: estimates, patterns, and threats. PlosOne 5:e11842

Coma R, Ribes M, Gili JM, Zabala M (2000) Seasonality in coastal benthic ecosystems. Trends Ecol Evol 15:448-453

Conradi BM, Bandera GME, López González P (2006) The copepods associated with the coral Astroides calycularis (Scleractinia, Dendrophyllidae) in the Strait of Gibraltar. J Nat Hist 40:739-757

> D'Onghia G, Maiorano P, Sion L, Giove A, Capezzuto F, Carlucci R, Tursi A (2010) Effects of deep-water coral banks on the abundance and size structure of the megafauna in the Mediterranean Sea. Deep-Sea Res II 57:397-411

> Dean RL, Connell JH (1987) Marine invertebrates in an algal succession. III. Mechanisms linking habitat complexity with diversity. J Exp Mar Biol Ecol 109:249-273

Defant A (1961) Physical oceanography. Pergamon Press, London

Fredj G, Bellan-Santini D, Menardi M (1992) État des connaissances sur la faune marine méditerranéenne. Bull Inst Océanogr Monaco 9:133-145

García-Gómez JC (2007) Biota litoral y vigilancia ambiental en las Áreas Marinas Protegidas. Junta de Andalucía, Consejería de Medio Ambiente, Sevilla

García-Muñoz JE, Manjón-Cabeza ME, García-Raso E (2008) Decapod crustacean assemblages from littoral bottoms of the Alborán Sea (Spain, west Mediterranean Sea): spatial and temporal variability. Sci Mar 72: 437-449

Giaccone G (1999) L'origine della biodiversità vegetale del Mediterraneo. Not Soc Ital Biol Mar 35:35-51

Gofas S, Moreno D, Salas C (2011) Moluscos Marinos de Andalucía, Vol 1. Servicio de Publicaciones e Intercambio Científico, Universidad de Málaga

Goffredo S, Caroselli E, Gasparini G, Marconi G, Putignano MT, Pazzini C, Zaccanti F (2011) Colony and polyp biometry and size structure in the orange coral Astroides calycularis (Scleractinia: Dendrophylliidae). Mar Biol Res $7: 272-280$

> Guerra-García JM, Izquierdo D (2010) Caprellids (Crustacea: Ampipoda) associated with the intertidal alga Corallina elongata along the Iberian Peninsula. Mar Biodivers Rec 3:1-7

Guerra-García JM, Maestre MJ, González AR, GarcíaGómez JC (2006) Assessing a quick monitoring method using rocky intertidal communities as a bioindicator: a multivariate approach in Algeciras Bay. Environ Monit Assess 116:345-361

Guerra-García JM, Cabezas MP, Baeza-Rojano E, Espinosa F, García-Gómez JC (2009a) Is the north side of the Strait of Gibraltar more diverse than the south side? A case study using the intertidal peracarids (Crustacea: Malacostraca) associated to the seaweed Corallina elongata. J Mar Biol Assoc UK 89:387-397

Guerra-García JM, Sánchez JA, Ros M (2009b) Distributional and ecological patterns of caprellids (Crustacea: Amphipoda) associated with the seaweed Stypocaulon scoparium in the Iberian Peninsula. Mar Biodivers Rec 2: $1-8$

Guerra-García JM, Baeza-Rojano E, Cabezas MP, GarcíaGómez JC (2010) Vertical distribution and seasonality of peracarid crustaceans associated with intertidal macroalgae. J Sea Res 65:256-264

Guerra-García JM, Cabezas MP, Baeza-Rojano E, Izquierdo D and others (2011) Abundance patterns of macrofauna associated to marine macroalgae along the Iberian Peninsula. Zool Baetica 22:3-17

> Guerra-García JM, Ros M, Izquierdo D, Soler-Hurtado MM (2012) The invasive Asparagopsis armata versus the native Corallina elongata: differences in associated peracarid assemblages. J Exp Mar Biol Ecol 416-417: 121-128

- Hixon MA, Menge BA (1991) Species diversity: prey refuges modify the interactive effects of predation and competition. Theor Popul Biol 39:178-200

Holt RD (1987) Prey communications in patchy environments. Oikos 50:276-290

> Izquierdo D, Guerra-García JM (2011) Distribution patterns of the peracarid crustaceans associated with the alga Corallina elongata along the intertidal rocky shores of the Iberian Peninsula. Helgol Mar Res 65:233-243

Jones CG, Lawton JH, Shachak M (1994) Organisms as ecosystem engineers. Oikos 69:373-386

Keith DE (1971) Substrate selection in caprellid amphipods of southern California, with emphasis on Caprella californica Stimpson and Caprella equilibra Say (Amphipoda). Pac Sci 25:387-394

Koukouras A, Kühlmann D, Voultsiadou E, Vafidis D, Dounas C, Chintiroglou C, Koutsoubas D (1998) The macrofaunal assemblage associated with the scleractinian coral Cladocora caespitosa (L.) in the Aegean Sea. Ann Inst Océanogr 74:97-114

Kružic P (2014) Bioconstructions in the Mediterranean: present and future. In: Goffredo S, Dubinsky Z (eds.) The Mediterranean Sea: its history and present challenges. Springer, Dordrecht, p 435-447

Kružic P, Sršen P, Cetinic K, Zavodnik D (2013) Coral tissue mortality of the coral Cladocora caespitosa caused by gastropod Coralliophila meyendorffi in the Mljet National Park (eastern Adriatic Sea). J Mar Biol Assoc UK 93:2101-2108

Kružic P, Zibrowius H, Pozar-Domac A (2002) Actiniaria and Scleractinia (Cnidaria, Anthozoa) from the Adriatic Sea: first records, confirmed occurrences and significant range extensions of certain species. Ital J Zool 69: $345-353$

López E (1995) Anélidos poliquetos de sustratos duros de las Islas Chafarinas. $\mathrm{PhD}$ thesis, Universidad Autónoma de Madrid

Mastrototaro F, D'Onghia G, Corriero G, Matarrese A and others (2010) Biodiversity of the white coral bank off Cape Santa Maria di Leuca (Mediterranean Sea): an update. Deep-Sea Res II 57:412-430

Meesters EH, Hilterman M, Kardinaal E, Keetman M, deVries M, Bak RPM (2001) Colony size frequency distributions of scleractinian coral populations: spatial and interspecific variation. Mar Ecol Prog Ser 209:43-54

> Menge BA (1976) Organization of New England rocky intertidal community: role of predation, competition, and environmental heterogeneity. Ecol Monogr 46:355-393

Morri C, Peirano A, Bianchi CN (2001) Is the Mediterranean coral Cladocora caespitosa an indicator of climatic change? Archo Oceanogr Limnol 22:139-144

Neto AI (2000) Observations on the biology and ecology of selected macroalgae from the littoral of São Miguel (Azores). Bot Mar 43:483-498

- Nozawa Y, Tokeshi M, Nojima S (2008) Structure and dynamics of a high-latitude scleractinian coral community in Amakusa, southwestern Japan. Mar Ecol Prog Ser 358:151-160 
Ocaña A, Sánchez Tocino L, López-González PJ (2000) Faunistic and biogeographical observations concerning the Anthozoa (Cnidaria: Anthozoa) of the Granada coast (Sea of Alboran). Zool Baetica 11:51-65

Pacios I, Guerra-García JM, Baeza-Rojano E, Cabezas MP (2011) The non-native seaweed Asparagopsis armata supports a diverse crustacean assemblage. Mar Environ Res 71:275-282

Peirano A, Morri C, Bianchi NC (1999) Skeleton growth and density pattern of the temperate, zooxanthellate scleractinian Cladocora caespitosa from the Ligurian Sea (NW Mediterranean). Mar Ecol Prog Ser 185:195-201

> Pereira SG, Lima FP, Queiroz NC, Ribeiro PA, Santos AM (2006) Biogeographic patterns of intertidal macroinvertebrates and their association with macroalgae distribution along the Portuguese coast. Hydrobiologia 555: 185-192

Pérez-Cirera JL, Maldonado JL (1982) Principales tipos de vegetación bentónica y su zonación en el litoral comprendido entre las rías de Camariñas y de Corme y Lage (Costa de Camelle, La Coruña). Collect Bot 13:893-910

Piazzi L, Balata D, Pertusati M, Cinelli F (2004) Mediterranean coralligenous phytobenthic assemblages: temporal dynamics and influence of substrate inclination. Bot Mar 47:105-115

Porras R, Bataller JV, Murgui E, Torregrosa MT (1996) Trophic structure and community composition of polychaetes inhabiting some Sabellaria alveolata (L.) reefs along the Valencia Gulf coast, Western Mediterranean. Mar Ecol 17:583-602

Richter A, Luque AA (2004) Epitonium dendrophylliae (Gastropoda: Epitoniidae) feeding on Astroides calycularis (Anthozoa, Scleractinia). J Molluscan Stud 70:99-101

Roberts M (1978) Active speciation in the taxonomy of the genus Cystoseira C. Agardh. In: Irvine DEG, Price JH (eds) Modern approaches to the taxonomy of the red and brown algae. Academic Press, London, p 399-422

Rossi L (1971) Cnidari e Ctenofori d'Italia. Quaderni della Civica Stazione Idrobiologica di Milano 2:77-86

Sánchez-Moyano JE, García-Gómez JC (1998) The arthropod community, especially crustacean, as a bioindicator in Algeciras Bay (southern Spain) based on a spatial distribution. J Coast Res 14:1119-1133

Sánchez-Moyano JE, García-Adiego EM, Estacio FJ, García-Gómez JC (2000) Effects of environmental factors on the spatial distribution of the epifauna of the alga Halopteris scoparia in Algeciras Bay, southern Spain. Aquat Ecol 34:355-367

Editorial responsibility: Riccardo Cattaneo-Vietti, Ancona, Italy
Shannon CE, Weaver W (1963) The mathematical theory of communications. University of Illinois Press, Urbana, IL

Soler MM, Guerra-García JM (2011) Study of the crustacean community associated to the invasive seaweed Asparagopsis armata (Harvey, 1855) along the coast of the Iberian Peninsula. Zool Baetica 22:33-49

Taviani M, Angeletti L, Dimech M, Mifsud C, Freiwald A, Harasewych MG, Marco O (2009) Coralliophilinae (Gastropoda: Muricidae) associated with deep-water coral banks in the Mediterranean. Nautilus 123:106-112

Terrón-Sigler A, León-Muez D (2009) El impacto del buceo en el coral naranja. Quercus 281:28-33

Terrón-Sigler A, Moreno-Tempestini L, Jiménez-Martínez $\mathrm{B}$, Aguilar-Domínguez MD, Gutiérrez-Alba V, LeónMuéz D (2008) El coral naranja (Astroides calycularis); estudio, dinámica de población y medidas de gestión de un recurso natural endémico. XV Simposio Ibérico de Estudios del Bentos Marino, Funchal, Madeira

Thom R, Miller B, Kennedy M (1995) Temporal patterns of grazers and vegetation in a temperate seagrass system. Aquat Bot 50:201-205

Tortonese E (1985) Distribution and ecology of endemic elements in the Mediterranean fauna (fishes and echinoderms). In: Moraitou-Apostolopoulou M, Kiortsis V (eds) Mediterranean marine ecosystems. Plenum Press, New York, NY, p 57-83

Underwood AJ, Chapman MG, Richards SA (2002) GMAV5 for Windows: an analysis of variance programme. Centre for Research on Ecological Impacts of Coastal Cities, Marine Ecology Laboratories, University of Sydney

Vermeij MJA, Bak RPM (2002) Inferring demographic processes from population size structure in corals. Proc 9th Int Coral Reef Symp 1:589-593

Zibrowius H (1978) Les scléractiniaires des grottes sousmarines en Méditerranee et dans l'Atlantique nordoriental (Portugal, Madére, Canaries, Azores). Pubbl Stn Zool Napoli 40:516-545

Zibrowius H (1980) Les scléractiniaires de la Mediterranée et de l'Atlantique nord-oriental. Mem Inst Oceanogr (Monaco) 11:1-284

Zibrowius H (1983) Nouvelles données sur la distribution de quelques scléractiniaires 'méditerranéens' á l'Est et é l'Ouest du détroit de Gibraltar. Rapp p-v Reun, Bull Comm Int Explor Sci Mer Mediterr 28:307-309

Zibrowius H (1995) The "southern" Astroides calycularis in the Pleistocene of the northern Mediterranean an indicator of climatic change (Cnidaria, Scleractinia). Geobios 28:9-16

Submitted: February 10, 2014; Accepted: May 23, 2014 Proofs received from author(s): July 14, 2014 